\title{
MONOGRAFIE/MONOGRAPH
}

Valérie Tothová, Věra Hellerová (eds) (2021). Využití měřicích nástrojů v ošetřovatelství [Use of measuring instruments in nursing]. Praha. NLN, s. r. o. 225 s. ISBN 978-80-7422-817-9. DOI: 10.32725/zsf.2021.74228179

\section{Měřicí nástroje v ošetřovatelství}

kap. 3: DOI: 10.32725/zsf.2021.74228179.01

\section{Valérie Tóthová}

University of South Bohemia in České Budějovice, Faculty of Health and Social Sciences, Institute of Nursing, Midwifery and Emergency Care, České Budějovice, Czech Republic

\section{Souhrn}

Měření je systematický proces kvantifikace charakteristik osoby, jevu nebo situace. Měření není jenom součástí vědeckého výzkumu, ale je i součástí posuzování a hodnocení stavu pacienta v rámci ošetřovatelského procesu.

Kapitola popisuje význam měřicích nástrojů v ošetřovatelství, postup při výběru nástrojů, validitu a reliabilitu a postup při vytváření nových nástrojů. $V$ závěru této kapitoly jsou uvedeny $i$ jednotlivé fáze lingvistické validizace měřicích nástrojů.

Klíčová slova: lingvistická validizace, měřicí nástroje, ošetřovatelství, reliabilita, validita

\section{Podkapitoly:}

3.1 Výběr nástrojů

3.2 Validita a reliabilita nástrojů

3.3 Postup při vytváření nástroje měření

3.4 Lingvistická validizace měřicích nástrojů

\section{Literatura}

1. Blanař, V., et al. (2014) Česká verze dotazníku Hearing Handicap Inventory for Adults. Otorinolaryngol Foniatr 63(1): 50-57.

2. Bóriková, I., Žiaková, K., Gurková, E. (2009). Meranie a merací nástroj. In : Žiaková, K., a kol. Ošetrovatel'stvo - teória a vedecký výzkum. Martin: Osveta, s. 206-222.

3. Doenges, M. E., Moorhouse, M. F. (2013). Application of Nursing proces and Nursing Diagnosis an Interactive Text for Diagnostic Reasoning. Philadelphia: F. A. Davis Company.

4. Gurková, H. (2011). Hodnocení kvality života. Pro klinickou praxi a ošetřovatelský výzkum. Praha: Grada, $224 \mathrm{~s}$.

5. Hendl, J., Remr, J. (2017). Metody výzkumy a evaluace. Praha: Portál.

6. Holubová, M., et al. (2017). Postup validizace dotazníku Osteoarthritis Knee and Hip Quality of Life OAKHQOL. Evaluační teorie a praxe 5(1): 35-51. DOI : 10195/70211.

7. Kudlička, J. (2009). Reliabilita a validita kvantitatívneho výzkumného nástroja. In : Žiaková, K., a kol. Ošetrovatel'stvo - teória a vedecký výzkum. Martin: Osveta, s. 225-227.

8. Libová, L., et al. (2018). Hodnotiace nástroje a ich využívanie u seniorov. Zdravotnické listy 6(1): 33-39.

9. Mandysová, P., Hlaváčková, E. (2010). Translating foreign-developed instruments to guide nursing practice in the Czech Republic: do they encourage evidence-based nursing? Profese on-line III(3): 165174.

10. Pokorná, A., a kol. (2013). Ošetřovatelství v geriatrii. Hodnoticí nástroje. Praha: Grada, $202 \mathrm{~s}$. 
11. Tóthová, V., a kol. (2014). Ošetřovatelský proces a jeho realizace. 2., aktual. vyd. Praha: Triton, 226 s.

12. Vöröšová, G., Solgajová, A., Archalausová, A. (2015). Ošetřovatelská diagnostika v práci sestry. Praha: Grada, 208 s.

13. Vyhláška č. 55/2011 Sb., o činnostech zdravotnických pracovníků a jiných odborných pracovníků, ve znění pozdějších předpisů. In: Sbírka zákonů České republiky, částka 20/2011, s. 482-543. 